\title{
Institutional dimensions of farmland conservation: Applying the institutional analysis and development (IAD) framework to the U.S. Conservation Reserve Program
}

\author{
Kerri Morrison ${ }^{a}$ \\ McDaniel College \\ Scott D. Hardy ${ }^{\text {* }}$ * \\ Case Western Reserve University
}

\begin{abstract}
Submitted November 11, 2013 / Revised January 20 and March 6, 2014 / Accepted March 7, 2014 /
Published online September 11, 2014

Citation: Morrison, K., \& Hardy, S. D. (2014). Institutional dimensions of farmland conservation: Applying the institutional analysis and development (IAD) framework to the U.S. Conservation Reserve Program. Journal of Agriculture, Food Systems, and Community Development, 4(4), 21-33.

http://dx.doi.org/10.5304/jafscd.2014.044.006

Copyright (C) 2014 by New Leaf Associates, Inc.
\end{abstract}

\begin{abstract}
The Conservation Reserve Program (CRP) invites agricultural producers in the U.S. to voluntarily place land into conservation for 10 to 15 years. The program currently focuses on reducing soil erosion, increasing soil health, providing wildlife habitat, and improving water quality throughout the United States. This study employs a theoretical framework for the understanding of collective action institutions (sets of rules prohibiting, requiring, or permitting specified actions that are established to overcome common problems) in order to examine
\end{abstract}

\footnotetext{
${ }^{a}$ Kerri Morrison, Environmental Studies Department, McDaniel College; 2 College Hill; Westminster, Maryland 21157 USA.

$\mathrm{b} *$ Corresponding author: Scott D. Hardy, Office of Undergraduate Studies, Case Western Reserve University; 10900

Euclid Avenue; Cleveland, Ohio 44106 USA;

ScottHardy99@hotmail.com
}

the external factors, internal structures, and policy decisions of CRP and the impacts these variables have on program outcomes. We collected the data using open-ended, structured interviews with stakeholders associated with the program, and from government documents produced on the CRP by the U.S. Department of Agriculture (USDA) and other local, state, and federal agencies. Results indicate that the biophysical environment, local culture, and institutional rules greatly contribute to program implementation (resources for conservation, decision-making structures, and management strategies) and outcomes (amount and type of land conserved, and level of participation by agricultural landowners).

\section{Keywords}

Conservation Reserve Program, farmland conservation, Food Security Act, institutional analysis and development (IAD) framework, policy analysis 


$\begin{array}{ll}\begin{array}{l}\text { Abbreviations } \\ \text { CCC } \\ \text { CREP }\end{array} & \begin{array}{l}\text { Commodity Credit Corporation } \\ \text { Conservation Reserve Enhancement } \\ \text { Program }\end{array} \\ \text { CRP } & \begin{array}{l}\text { Conservation Reserve Program } \\ \text { CSREES }\end{array} \\ & \begin{array}{l}\text { Cooperative State Research, Education and } \\ \text { Extension Service }\end{array} \\ \text { EBI } & \text { Environmental Benefits Index } \\ \text { EFCRP } & \begin{array}{l}\text { Emergency Forestry Conservation Reserve } \\ \text { Program }\end{array} \\ \text { FSA } & \text { Farm Service Agency of the USDA } \\ \text { FWP } & \text { Farmable Wetlands Program } \\ \text { IAD } & \begin{array}{l}\text { Institutional analysis and development } \\ \text { NGO }\end{array} \\ \text { Nongovernmental organization } \\ \text { NRCS } & \text { Natural Resource Conservation Service } \\ \text { TIP } & \text { Transitions Incentives Program } \\ \text { USDA } & \text { U.S. Department of Agriculture }\end{array}$

\section{Introduction}

Farming is a vital component of food security in the United States; however, a balance must be struck between maximizing crop yield today and conserving farmland for environmental sustainability and use in the future. According to the U.S. Department of Agriculture, over 13 million acres (5 million hectares) of cropland have been lost to development in the last 30 years, and approximately 1.0 billion tons of agricultural soil is lost to erosion annually (USDA, 2013d). In an effort to combat these trends, the U.S. Congress created the Conservation Reserve Program (CRP) as part of the Food Security Act of 1985. Commonly called the farm bill, this legislation, along with CRP, is renewed and revised approximately every five to six years and remains in effect today. As one of the few voluntary, national government programs to focus specifically on long-term farmland conservation, CRP is an integral component of land preservation and environmental management in the U.S. Since the program is run using limited governmental funds, it is vital that CRP provide the maximum conservation benefits possible under the most cost-efficient structure.

To examine CRP and its effectiveness, we employed a theoretical framework to isolate the variables impacting policy, management, and implementation decisions. The institutional analysis and development (IAD) framework developed by
Elinor Ostrom and her colleagues has been shown to be successful in analyzing ecosystem management programs (Imperial, 1999) and will direct this investigation. The IAD framework provides a method to identify the environmental, cultural, and institutional variables that affect the decisions made within an environmental management institution, and the resultant outcomes (Kiser \& Ostrom, 1982). This framework can thus help to reveal strengths and weaknesses of CRP as an environmental management strategy, as well as provide transparency to the decision-making processes connected to the program by isolating the factors that influence policy decisions and outcomes.

\section{The Institutional Analysis and Development Framework}

The IAD framework was developed by Kiser and Ostrom (1982) to provide a means through which the complex decisions made by any particular institution could be broken down into components for analysis. The framework can then help researchers determine which specific factors influence decision-making behavior within the institution and the resulting outcomes (Kiser \& Ostrom, 1982). This is especially useful when examining CRP, since the program is governed by a variety of agencies at differing levels of government and is participated in by farmers on a voluntary basis. Imperial (1999) argues that the IAD framework is particularly effective for ecosystem-based management systems because it addresses not only institutional rules, but also biophysical and cultural influences. Therefore it is an appropriate framework with which to analyze CRP, since the program involves the conservation of particular environments and requires the input of a specific subgroup of the population: farmers. The IAD framework also examines the impact of human behavior on the institution and vice versa, which is particularly important when dealing with programs that are designed to influence human behavior (Imperial, 1999), such as changing how a farmer uses a particular piece of land.

\section{Concepts and Variables}

The IAD framework outlines three external factors 
that influence the decision-making process and outcomes of an institution (see Figure 1). The first is the biological and physical environment (Ostrom, Gardner, \& Walker, 1994). This variable is particularly important when analyzing CRP since conservation decisions are made by Farm Service Agency (FSA) and Natural Resource Conservation Service (NRCS) officials according to specific environmental criteria (USDA, 2013a). Thus the biological and physical environment has a direct impact on which lands are selected for participation in the program. The second factor is the community, which includes all the individuals who are involved in and affected by the decisions made in the institution (Kiser \& Ostrom, 1982). One significant aspect of the community variable of CRP is the agricultural community, including landowners and farm operators, which constitute a specific cultural group. Without collaboration from these key stakeholders the program would not exist. The final factor is the institutional rules and behavioral norms that affect decision-making (Kiser \& Ostrom, 1982). These rules include formal policy rules, such as legislation implementing CRP, and informal rules, such as a typical method of inter- action between agency employees and producers (Kiser \& Ostrom, 1982). Again, without the financial, technical, and human resources established by institutional rules, CRP would not be viable.

These factors are then examined in the context of the "action arena," which is all the individuals who interact to make decisions that affect the outcomes of the institution (Ostrom, 2011). For CRP, the action arena includes producers who participate in the program, state and local officials who implement and enforce the program, private nongovernmental organizations (NGOs) that assist in implementation, and policy-makers who dictate the overarching rules. Decisions are made in the action arena, affected by the external variables, and ultimately generate outcomes (Kiser \& Ostrom, 1982). The IAD framework can be used to both predict potential outcomes and evaluate measurable outcomes (Ostrom, 1999). Since the framework isolates the external variables and the connections between those variables and the outcomes, both the outcomes themselves and the processes that lead to those outcomes can be evaluated (Ostrom, 1999). Thus, the framework can be used to identify

\section{Figure 1. Model of the Institutional Analysis and Development Framework}

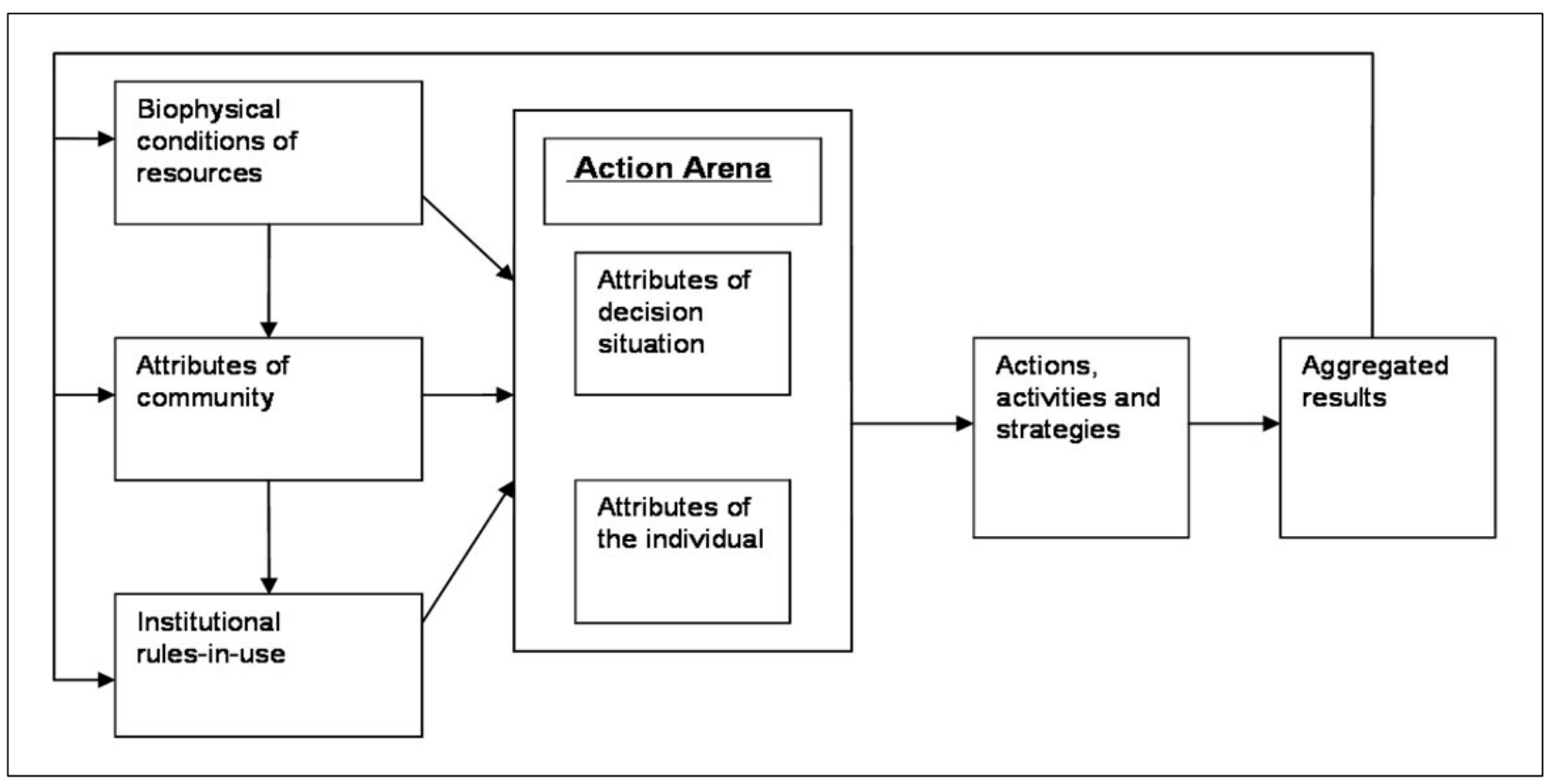

Adapted from Rules, Games, and Common-Pool Resources, by E. Ostrom, R. Gardner, \& J. Walker, 1994, Ann Arbor, Michigan: The University of Michigan Press, p. 37. Copyright C 1994 by The University of Michigan Press. 
strengths and weaknesses in the program, potential solutions for recurring problems, and methods to increase efficiency (Ostrom, 1999).

\section{Methods}

As stated, this study employs the IAD framework to examine CRP. To employ the framework, we collected information from research articles, government documents, and stakeholder accounts on the structure, implementation, and outcomes of CRP. We conducted ten interviews with key stakeholders associated with the program to gather information on the biophysical, cultural, and institutional factors affecting CRP. Interview participants were identified using a snowball sampling method, beginning with local governmental officials affiliated with CRP through positions in relevant agencies. At least one interview was conducted with an official at three levels of government: federal, state, and local. Agency officials interviewed were associated with FSA, NRCS, the Maryland Department of Agriculture, and University of Maryland Cooperative Extension. Some of these officials were tasked with operational activities associated with implementing the program, while others were more closely aligned with policy matters. We conducted additional interviews with producers who participate in CRP.

Interviews were conducted using an interview guide of 14 open-ended questions related to the IAD framework. Individual questions were operationalized to correlate to specific IAD variables. For example, respondents were asked how local biophysical conditions, community attributes, and institutional rules-in-use (rules that govern affiliated actors and actions) affect CRP implementation and outcomes in their region, as well as questions about the key actors and actions associated with the program. All but one of the interviews were conducted in person or over the phone, based on availability of the researchers and interviewees and geographical location. Each interview lasted approximately 30 minutes, and all interviews were conducted during March and April 2013. One interview was conducted via email due to time constraints on the part of the interviewee. All participants were informed of the purpose of the interview and consented to participate. Confiden- tiality of names and positions was guaranteed. Once the interviews were conducted and all relevant secondary research compiled, we then analyzed this information using the IAD framework according to the biophysical environment, community attributes, institutional rules, and program outcomes.

\section{Results}

\section{Biophysical Environment}

To be considered for CRP, land must be legally classified as capable of being planted, must be considered highly erodible, and must be located in a priority conservation area, or have been previously enrolled in CRP (USDA, 2013a). For general sign-up, the most common method of enrollment, lands are ranked based on six factors that make up what is called the Environmental Benefits Index (EBI): benefits the land can provide to wildlife, potential to improve water quality through soil retention and nutrient absorption, reduction of soil erosion, benefits that have the potential to last beyond the CRP contract, potential to improve air quality, and cost of renting the land (Hamilton, 2010; USDA, 2013a). The EBI was developed by FSA and NRCS. Producers with the highest scores on the EBI are deemed to have the most environmentally sensitive land that can support the most cost-effective conservation methods and are selected for enrollment (USDA, 2013a). These producers are then offered contracts to put their farmland into retirement for either 10 or 15 years, depending on their preference.

In contrast to the general sign-up process, the continuous sign-up process is targeted specifically to marginal and environmentally sensitive lands (USDA, 2006a). These lands meet certain environmental eligibility criteria determined by FSA as critically important to conserve (USDA, 2006a). Land eligibility requirements for continuous signup follow particular initiatives set by FSA that target specific environmental goals (Stubbs, 2013). These initiatives and FSA goals for each are listed in Table 1.

The biophysical environment plays a major role in on-the-ground implementation as well. NRCS technicians work with producers to identify 
land that is less productive and environmentally sensitive, helping the producers to develop a conservation plan (USDA, 2012). While the producer ultimately decides what conservation practices will be used, the environment dictates which practices are most attractive. Factors that influence type of conservation also include soil erodibility, landscape, bodies of water, size of farm, type of farm, presence of animals, climate, species, and growing season (USDA, 2012). FSA additionally uses aerial maps to determine the most environmentally sensitive land, both on regional and individual farm scales (USDA, 2012).

CRP is designed to work in conjunction with federal, state, and local agricultural regulations and conservation programs. For example, in Maryland regulations were recently enacted to reduce nutrient runoff from agriculture. Producers will be able to enter land now required to be protected under Maryland law into CRP, gathering rental payments on the land and cost-share assistance for conservation measures taken on it. The combination of CRP with state and local government initiatives is exemplified by a subset of CRP, the Conservation Reserve Enhancement Program (CREP). Partici-

Table 1. FSA CRP Initiatives and Acreage under Continuous, Non-Conservation Reserve Enhancement Program (CREP) Sign-Up

\begin{tabular}{lccc}
\hline Initiatives & $\begin{array}{c}\text { FSA Goal } \\
\text { (Acres Enrolled } \\
\text { Nationally) }\end{array}$ & $\begin{array}{c}\text { First Year } \\
\text { of Initiative }\end{array}$ & $\begin{array}{c}\text { Total Acres } \\
\text { Enrolled }\end{array}$ \\
\hline Flood-plain wetlands & 600,000 & 2004 & 231,607 \\
Bottomland hardwood trees & 250,000 & 2004 & 84,645 \\
Non-flood plain and playa wetlands & 350,000 & 2005 & 226,820 \\
Upland bird habitat buffers & 500,000 & 2005 & 241,851 \\
Longleaf pine plantings & 250,000 & 2007 & 116,909 \\
Duck nesting habitat & 300,000 & 2007 & 194,919 \\
$\begin{array}{l}\text { State acres for wildlife enhancement } \\
\text { (SAFE) }\end{array}$ & $1,250,000$ & 2008 & 70,713 \\
Highly erodible lands & 750,000 & 2012 & 43,737 \\
Pollinator habitat & 100,000 & 2012 & 835 \\
\hline
\end{tabular}

Note: 1 acre $=0.4$ ha

Source: U.S. Department of Agriculture, 2013b. pants in CREP have to put into place specific conservation measures that address state conservation goals, according to plans drafted by state and federal officials (USDA, 2006b).

The biophysical environment affects not only the decisions and actions of the government agencies implementing the program, but also the decisions of participants. New technologies allow farmers to pinpoint which acres of land are producing profitable returns and which may not be worth expending the cost to plant and harvest. Interview respondents indicated that if farmers recognize certain acres as unprofitable, they might see CRP as a more economically lucrative option. This decision-making process is advantageous because the unprofitable areas of land are usually the lands most environmentally sensitive and in need of conservation. These examples show how the structure of the program is well suited to its purpose of altering the biophysical landscape and how it is also heavily influenced by the environment.

Community Attributes

The most significant cultural group for CRP is the producers. For the purposes of this study, a farmer can be defined as the operator of a farm. Several studies have analyzed attitudes of farmers toward conservation practices (Lynne \& Rola, 1988; Lynne, Shonkwiler, \& Rola, 1988; Reimer, Thompson, \& Prokopy, 2012). In general, these studies have found that, while finances influence individual decisions to participate in conservation programs, attitudes toward conservation and sustainability also affect whether a farmer will choose to participate in a conservation program (Lynne \& 
Rola 1988; Lynne, Shonkwiler, \& Rola, 1988; Reimer et al., 2012). These findings were supported by interviews with stakeholders in this study. Some observed that the money gained through participation in CRP was the primary motivation for producers to enroll land in the program. However, these respondents also indicated that farmers with conservationist views were quick to enroll in CRP for the environmental benefits it provided; others were more motivated by the funding the program provides, while still others would likely never participate in the program due to individual views concerning governmental authority.

Some research has been conducted specifically on the motivation of producers to enter land into CRP (Chang \& Boisvert et al., 2009; Roberts \& Lubowski, 2007). Chang and Boisvert (2009) found that specific factors influenced whether a producer decided to enroll land in CRP and how much land he or she enrolled. Interviews conducted with stakeholders in this study confirmed Chang \& Boisvert's (2009) results that producers who were of retirement age were more likely to put entire fields into CRP rather than just sections of land. Additionally, producers who had careers outside of farming and/or had no intention of farming the land were more likely to put whole fields into CRP (Chang \& Boisvert, 2009). Again this was supported through stakeholder interviews. Respondents in this study revealed that location of farms could have an effect on enrollment in CRP. Farmers in areas close to urban and suburban centers are less likely to enroll in CRP because there is potential that developers may buy the land at a higher price than could be offered by CRP.

How the community uses the land can also have an effect on whether land is enrolled in CRP and whether there is public resistance to the program. To produce large enough quantities of crops to be profitable, farmers may have to rent large tracts of land from multiple landowners. If a landowner chooses to place land in CRP, it reduces the amount of farmland available to rent and may reduce profits for tenants. According to interview participants, this has led to opposition to CRP by farmers, especially in the past when CRP focused on whole-field conservation. To alleviate this conflict, Congress and the USDA have enacted regulations to ensure that contracts between tenants and landowners are not broken by the landowners participating in CRP, and that tenants receive compensation for the loss of land.

Community preferences influence the way in which CRP is implemented. According to participants in this study, some communities have an abundance of classifiable agricultural land but few farms in the area. These communities may prefer to use that land for conservation purposes (Nelson, Uwasu, \& Polasky, 2007). If there are certain environmental projects that are favored by the community, those projects can be targeted through CREP and the assistance of NGOs and state agencies. National public opinion and politics also influence the program. Changes to the program in 1990 reflected the desires of the public and of policymakers to make the program apply to additional environmental issues beyond only soil erosion (Hamilton, 2010). Interviews from this study also indicate that public opinion helps to keep CRP running.

The officials who implement the program are also a part of the community, as they decide which lands to enroll in CRP and which conservation measures will be used. Stakeholder interviews revealed that many of the officials working in the program feel a personal connection to the producers and the communities with which they work. Officials are highly motivated to provide producers with the maximum possible benefits and put in place effective conservation measures. They seek to improve environmental attributes of the state, while also improving the farmer's land. Stakeholders interviewed for this study described CRP as a program in which producers can take pride. It provides producers with the economic and technical opportunity to participate in conservation and contribute to the well-being of their state and county. Stakeholders interviewed in this study have observed an overall increasing acceptance among the public and the farming community for CRP.

\section{Institutional Rules}

The basic structure and purposes of CRP are set through the farm bill. Federal statute mandates that CRP is to be administered by FSA and rental payments made through the Commodity Credit 
Corporation (CCC), a federal corporation operated under the USDA. The program is implemented through a number of federal, state, and local agencies (Food, Conservation, and Energy Act, 2008). FSA approves the conservation plans, and determines and pays rental and cost-share payments. NRCS (or other organizations approved by NRCS, such as the Cooperative State Research, Education and Extension Service (CSREES), employees of state agencies, or private conservation consultants) determines the conservation measures that can be taken on pieces of land (Food, Conservation, and Energy Act, 2008; USDA, 2006b) and assists the producer in building a conservation plan to submit to FSA (USDA, 2012). Federal statute also allows for the consultation of other agencies as necessary, such as state forestry and wildlife agencies and the U.S. Fish and Wildlife Service. Additionally, the statute sets many of the definitions that govern CRP, including specific biophysical characteristics, enforcement and implementation mechanisms, and economic terms.

The farm bill mandates that CRP be a voluntary program that producers can enter into and in return receive payment for the cost of renting the land, as well as up to half the cost of implementing conservation measures as determined by FSA and NRCS and approved by that county's conservation district. Federal statute limits CRP to 25 percent of agricultural land in each county. However, if FSA can show that having more than 25 percent of a county's agricultural land enrolled in CRP will not have a negative impact on the local economy, that limit can be waived (Food, Conservation, and Energy Act, 2008). Limits are also placed on what lands can be enrolled in CRP in order to ensure that agricultural land specifically is being targeted by the program (Food, Conservation, and Energy Act, 2008). The statute is flexible enough to allow FSA to determine which lands are the most environmentally sensitive and thus the highest priority for conservation, what conservation measures should be taken for land with particular attributes, and which lands should be eligible for continuous sign up. The statute additionally gives FSA the authority to determine acceptable uses and practices of the enrolled land, such as how often the land can be grazed. The federal statute outlines legal consequences of violating the laws under the program or presenting false information. Finally, the statute provides a means by which interested producers and tenants of farmland can be treated fairly under CRP.

CRP relies on interagency cooperation. Officials at the state and local level, usually employees with conservation districts, state research extension programs, or NRCS, explain conservation measures to producers and landowners, helping them to create a single conservation plan that includes national conservation measures, such as CRP and NRCS programs, as well as fulfills state conservation requirements (USDA, 2012). According to stakeholders interviewed at the state and local levels, one of the major goals of officials working with producers is to give the landowner the maximum financial benefit in accordance with the physical qualities of the land, state regulations, and preferences of the producer. Federal employees interviewed for this study were in agreement that often the most environmentally sensitive land (and thus land that ranks higher on the EBI) is unprofitable and/or must be conserved under state law. CRP provides a means through which the producer can conserve that land in fulfillment of state regulations, while still receiving payments for putting the land out of use and receiving a significant reduction in the cost of implementing the necessary conservation measures.

While the farm bill is only renewed every five to six years, the statute is broad enough to allow many of the specific elements of CRP to be regulated internally by the USDA. Therefore there are nearly constant minor policy changes to the CRP regulations. Stakeholders interviewed for this study indicated that most major policy changes (e.g., changes to federal statute or significant additions or subtractions to the program) are either political or economic in nature. Debates over the 2012 farm bill caused the passage of the bill to be delayed, with an extension of the 2008 farm bill passed in its place. This has halted the process for new enrollment in CRP. Economically, policy changes occur to reflect changes in the market price of commodities. Additionally the overall economic state of the country can affect the amount of money spent on agricultural conservation. 
In general, CRP tends to correlate well with state priorities. FSA and NRCS officials consistently work with state agricultural, fish and wildlife, and forestry agencies to ensure that the conservation methods employed by producers with land enrolled in CRP are beneficial to the state's environmental priorities (USDA, 2012). For example, stakeholders described the input of state forestry agents in the program as vital to tree planting. FSA and NRCS officials interviewed for this study described how they have learned to work in conjunction with other agencies to ensure that there are few, if any, negative impacts resulting from the conservation practices taken as a part of CRP. Often officials with state agencies are the most knowledgeable of native species and how the ecosystem functions. This knowledge can be invaluable to implementing the program in a costeffective and environmentally beneficial manner. Agency cooperation is furthered through the use of CREP and Farmable Wetlands Program (FWP) so that states can target funding to regional priorities (USDA, 2006b).

\section{Outcomes}

CRP has produced an abundance of environmental outcomes, as well as some social outcomes. Not all of these outcomes are easily measured or neces- sarily beneficial to the environment. According to the federal law that created CRP, the purpose of the program is to:

Cost-effectively reduce water and wind erosion, protect the Nation's long-term capability to produce food and fiber, reduce sedimentation, improve water quality, create and enhance wildlife habitat, and other objectives including encouraging more permanent conservation practices and tree planting. (Food Security Act, 1985, \1410.3, para. c)

Thus, if CRP is functioning in correlation with its legislative intent, these outcomes should result from the program, either directly or indirectly. The success of CRP is generally measured in acres of land conserved through the program, and then effects are extrapolated based on knowledge of how many acres are in conservation and which conservation measures are in practice (USDA, 2013a). Table 2 shows the number of acres enrolled in CRP.

Some outcomes of the program are more quantifiable than others. Reductions in soil erosion are definitively measurable, according to FSA officials. FSA can measure the soil erodibility of

Table 2. Land Enrolled in Conservation Reserve Program

\begin{tabular}{|c|c|c|c|c|c|}
\hline Type of Contract & $\begin{array}{l}\text { Number of } \\
\text { Contracts }\end{array}$ & $\begin{array}{l}\text { Number of } \\
\text { Farms }\end{array}$ & Number of Acres & $\begin{array}{l}\text { Annual Rental } \\
\text { Payments } \\
\text { (millions of US } \\
\text { dollars) }\end{array}$ & $\begin{array}{l}\text { Rental Payments } \\
\text { (US dollars per } \\
\text { acre) }\end{array}$ \\
\hline General & 291,191 & 194,915 & $21,521,915$ & $\$ 1,075$ & $\$ 49.94$ \\
\hline \multicolumn{6}{|l|}{ Continuous: } \\
\hline Non-CREP & 320,142 & 192,158 & $3,883,539$ & $\$ 361$ & $\$ 91.00$ \\
\hline CREP & 73,624 & 48,548 & $1,272,055$ & $\$ 170$ & $\$ 133.51$ \\
\hline FWP & 15,595 & 12,089 & 340,728 & $\$ 37$ & $\$ 109.90$ \\
\hline Total Continuous & 409,361 & 238,478 & $5,496,323$ & $\$ 568$ & $\$ 103.43$ \\
\hline Total CRP & 700,552 & 390,182 & $27,017,916$ & $\$ 1,643$ & $\$ 60.82$ \\
\hline
\end{tabular}

Source: U.S. Department of Agriculture, 2013b.

Note: 1 acre $=0.4$ ha 
land before and after conservation measures are implemented. Also, soil erodibility of the land is a component of EBI, meaning the producer is required to collect and provide that information prior to implementing conservation measures (USDA, 2013c).

One of the major issues with measuring success of the program is a lack of baseline data, which NRCS does not have either the authority or resources to collect. For example, the improvement of a stream's water quality cannot be measured if there is no original data to compare to the present day. Additionally, some environmental benefits are very difficult to quantify and to attribute to a single program or conservation effort (Giudice \& Haroldson, 2007). Despite widespread claims that CRP increases populations of bird species, Giudice and Haroldson (2007) showed that such claims are difficult to scientifically measure and verify. Some conservation measures have little to no effect for years, or even decades. Planting trees, for example, requires many years before environmental benefits can be observed. While one of the major goals of CRP is cost-effectiveness, this is almost impossible to measure since many of the environmental benefits alone cannot be measured adequately (Giudice \& Haroldson, 2007). Therefore, it is difficult to prove that all of the governmental funds supporting the program are worth the outcomes.

Several studies have been conducted to measure the success of wildlife management in the program (Dunn,, Stearns, Guntenspergen, \& Sharpe, 1993; Giudice \& Haroldson, 2007; Matthews, Taylor, \& Powell, 2012; Negus, Davis, \& Wessel, 2010; Swanson, Scott, \&, Risley, 1999). Agency officials keep track of this data and sometimes help fund the research. CRP land has been shown to increase biodiversity, decrease habitat fragmentation, and provide carbon sequestration (Dunn et al., 1993). The program has also increased the number of wetlands (Table 1), and stakeholders have observed increases in certain bird populations, particularly pheasants.

While CRP has numerous environmental benefits, there are some unintended negative effects on the environment and to farmers. One negative effect is the opportunity for invasive species to populate CRP land and spread further.
Stakeholders interviewed for this study indicated this is a problem because the land is being cleared and invasive species which may not be able to outcompete crops are sometimes able to outcompete native species planted for conservation. Another unintended effect identified by local officials working with CRP interviewed for this study is that pollen and seeds from CRP land are sometimes transported by wind to nearby land that is being used as cropland, interfering with production of that land. A further consequence local officials and landowners observe is an increased presence of deer because CRP lands often are a suitable habitat for them, especially in areas with tall, warmweather grasses that are a highly desirable for raising young. Deer pose a significant problem because they can damage crops, cause car accidents, and overgraze native plants. FSA has made considerable effort to try to reduce these negative effects by implementing adaptive conservation strategies and practices (USDA, 2012). However, further standards for maintaining and implementing conservation practices over the lifetime of the contracts could significantly improve environmental outcomes (Giudice \& Haroldson 2007; Matthews et al., 2012; Negus et al., 2010; Osborne, Sparling, \& Hopkins, 2012; Risley et al., 1999).

\section{Discussion}

\section{Biophysical Environment}

The biophysical environment has an enormous effect on decision-making concerning CRP at all levels of government. Environmental criteria are key to enrollment of land into CRP (USDA, 2013a). The use of the EBI for participation in CRP through general sign-up is a competitive process, based primarily on environmental aspects of the land (USDA, 2013c). The EBI process has been shown to be useful in targeting environmentally sensitive lands that can provide substantial environmental outcomes (Ribaudo, Hoag, Smith, \& Heimlich, 2001). FSA changes the requirements for EBI each year, and the point values assigned vary by state and sometimes by county (USDA, 2013c). This flexibility maintains the purposes of the program by ensuring that environmental issues that vary by geographical area and over time will be 
taken into proper consideration. This maximizes the use of conservation practices and helps to ensure that the most environmentally sensitive agricultural land is placed into CRP. EBI has resulted in CRP accomplishing a wider variety of conservation goals (Ribaudo et al., 2001).

The CREP, FWP, Emergency Forestry Conservation Reserve Program (EFCRP), and Transitions Incentives Program (TIP) are all additions to the original CRP that have not only increased environmental benefits but also have allowed those benefits to focus on specific areas of environmental concern (USDA, 2006b). CREP in particular has allowed land conservation in the program to focus on regional environmental problems (USDA, 2006b). This seems to be very beneficial to a national ecosystem management program. While some regions are well suited for CRP and whole-field conservation, the environment of other regions necessitates the use of specific environmental practices to help resolve significant environmental issues in those areas (USDA, 2013b). In some areas, without the addition of these programs it is likely that much less land would be enrolled in CRP today (USDA, 2013b). In Maryland, for example, local officials interviewed for this study observed that most of the land is under CREP, with existing CRP contracts being relatively old and likely to switch to CREP when they are up for renewal. These results can be attributed to higher land rental payments provided by CREP, since the Chesapeake Bay constitutes a conservation priority area (USDA, 2013b). Additionally, CREP works well in conjunction with state regulations and provides producers with a greater economic benefit than enrolling in general sign-up CRP (USDA, 2013b).

The FSA has attempted to reduce potential negative environmental outcomes of the program; it has made minor changes through internal policy and has made larger changes through the farm bill. NRCS and FSA are instructed to work closely with state and local governmental agencies, NGOs, and other local organizations to provide conservation measures that will be the most environmentally beneficial overall (USDA, 2012). FSA also has put regulations into place that specify management practices that must be undertaken for certain envi- ronments and conservation choices (USDA, 2012). For example, plants that spread quickly and easily have maintenance requirements to prevent their spread to nearby land (USDA, 2012). The FSA continues to incorporate many regulations like this by learning what measures work best in different environments and provide the most environmental and economic benefits (USDA, 2012).

\section{Community Attributes}

FSA has done a remarkable job in structuring and adjusting CRP to fit the agricultural community. First, the program is voluntary. Thus, it can be framed as the producer choosing to enact conservation practices to better the land and improve environmental quality for others. The voluntary basis of the program seems to reduce the feelings of resentment that may accompany mandatory conservation regulations. The producer also experiences some freedom in choosing the conservation methods, according to stakeholders interviewed for this study. NRCS officials take the producer's preferences into consideration as much as possible when designing a conservation plan and often generate multiple cost proposals for implementing conservation practices. One participant recognized the importance of this freedom, noting that it maintains the farmer's ability to control the environment. These methods also allow for social outcomes, such as the opportunity for hunting and the aesthetic value of the conserved land.

The FSA and NRCS officials working with the producer are usually assigned projects at the county level, and often live in the same counties as the producers themselves. This adds a degree of personal influence. The producer usually relies on NRCS officials to come up with a conservation plan, trusting that these officials know the many state and federal agricultural regulations. FSA and NRCS officials interviewed for this study indicated that most participants in the program sign up on the advice on NRCS technicians and noted that this personal interaction is more useful than outreach methods in drawing participation. This outcome suggests that NRCS perhaps should focus more on building community trust with the agency in order to gain more participants, a strategy that has been employed to improve environmental 
governance in other settings (see Ostrom, 2005). CRP has adjusted well to criticism from a variety of groups and interests. When the program was first initiated in 1985, it quickly received criticism that it was not cost-effective (U.S. General Accounting Office, 1989) and did not address enough environmental issues (Young, Bechtel, \& Coupal, 1994; Dunn et al., 1993; Reichelderfer \& Boggess, 1988). In response, CRP was modified to reflect a wider variety of environmental concerns, including habitat enhancement and water quality (USDA, 2013a). During the start of the program, tenants were concerned about losing profits from large tracts of land if landowners put whole fields into CRP. USDA responded by created mandates that ensure tenants are treated fairly and are compensated (USDA, 2012). Also, regulations on management have become more strict and specific to improve the effectiveness of these measures and prevent them from interfering with agricultural production elsewhere.

\section{Institutional Rules}

Policy decisions regarding CRP seem to be least effective at the federal level. The national political climate has led to reductions and delays in CRP. Congress extended the 2008 farm bill because an agreement could not be reached over the proposed 2012 farm bill. This extension has halted the enrollment process from many prospective CRP participants, causing stress to producers and a delay in implementing important conservation measures. Although the national structure of the program is helpful in ensuring benefits across the country, there are also delays. Every five to six years there is concern that funding and maximum acreage will be reduced again or that the program will be cut altogether.

FSA and NRCS implementers are efficient, well-coordinated, and constantly seeking to improve the program. FSA and NRCS officials interviewed for this study demonstrated appreciation for other agencies involved in the program and appeared to have well established connections at all levels of government. This seems to be a major benefit of the program, in that producers are receiving conservation plans that incorporate the goals of national, state, and local agencies in a cost- effective manner. Participants in this study view CRP as a great example of interagency cooperation, and there seem to be few to no conflicts between various agencies. In general, all the agencies involved have similar goals of helping the producer and improving the environment.

\section{Conclusion}

This study provides a unique contribution to the literature on farmland conservation by considering the institutional capacity of CRP. The ability of producers enrolled in CRP to conserve land is often influenced by external variables, including local biophysical conditions, local community attributes, and local, state, and federal institutional rules. We hope these findings will help to inform producers and farmland conservation practitioners about how these variables affect decision-making and resource allocation within CRP, and ultimately facilitate the enrollment of additional lands in CRP.

The structure of CRP is well suited to its purpose and appears to function according to congressional intent as mandated by the farm bill. Biophysical characteristics of the land are the major determinants for involvement in the program and the types of conservation practices that are enacted. The regulations on these characteristics are flexible enough to account for cultural variation as well as changes across time and space. Although there are some unintentional negative environmental outcomes, CRP places millions of acres of land into conservation each year, removing unproductive and unused land and repurposing it to benefit the environment and society. Producer attitudes are growing increasingly accepting of conservation programs, and involvement in CRP can be a source of pride for producers. FSA has structured the program in a way that appeals to producers and at times can help them to accomplish state and local conservation goals at a reduced cost or at no cost to the producers with additional financial assistance from the state. Although the national policy aspects of CRP appear ineffective, the program is implemented according to institutional rules that allow many groups to participate and work together to accomplish similar goals. Even though some of the environmental benefits of CRP are difficult to quantify, the observable outcomes fulfill the policy 
goals outlined by federal law and by FSA.

This study implicates that the CRP is a well functioning program that could use some improvements, especially in gathering baseline data and preventing unintended negative outcomes. However, the program demonstrates effective cooperation between various agencies and has changed over time to suit current conservation practices and needs. Continuation of the program is likely, and based on past history and current practices CRP will likely improve over time, continuing to maximize environmental outcomes and benefit agricultural producers.

While this study improves our understanding of CRP implementation and outcomes, it is not without its limitations. The small sample size and regional focus of interview participants mean that our findings cannot be considered representative of all key stakeholders associated with CRP, thus raising questions about the study's generalizability to a broader population. Furthermore, a larger $\mathrm{N}$ would result in more empirical data to inform the results and discussion. Looking forward, future research on this project could employ the full IAD framework, which also includes how external factors influence decisions at three levels of choice (Kiser \& Ostrom, 1982). Additionally, first-hand observation of CRP in action, such as shadowing an NRCS or FSA employee, would provide deeper insights into its institutional processes.

\section{References}

Chang, H.-H., \& Boisvert, R. N. (2009). Distinguishing between whole-farm vs. partial-farm participation in the Conservation Reserve Program. Land Economics, 85(1), 144-161.

Dunn, C. P., Stearns, F., Guntenspergen, G. R., \& Sharpe, D. M. (1993). Ecological benefits of the Conservation Reserve Program. Conservation Biology, 7(1), 132-139. http://dx.doi.org/10.1046/j.15231739.1993.07010132.x

Food, Agriculture, Conservation, and Trade Act of 1990, Pub. L. No. 101-624, 104 Stat. 3359. (1990).

Food, Conservation, and Energy Act, 16 U.S.C. \$21012210 and $\int 3801-3862$. (2008).

Food Security Act of 1985, U.S.C. \1410.3. (1985).

Giudice, J. H., \& Haroldson, K. J. (2007). Using regional wildlife surveys to assess the CRP: Scale and dataquality issues. Journal of Field Ornithology, 78(2), 140151. http://dx.doi.org/10.1111/j.15579263.2007.00097.x

Hamilton, J. T. (2010). Conserving data in the Conservation Reserve: How a regulatory program runs on imperfect information. Washington, D.C.: RFF Press.

Imperial, M. T. (1999). Institutional analysis and ecosystem-based management: The institutional analysis and development framework. Environmental Management, 24(4), 449-465.

http://dx.doi.org/10.1007/s002679900246

Kiser, L. L., \& Ostrom, E. (1982). The three worlds of action: A metatheoretical synthesis of institutional approaches. In E. Ostrom (Ed.), Strategies of political inquiry (pp. 179-222). Beverly Hills: SAGE.

Lynne, G. D., \& Rola, L. R. (1988). Improving attitudebehavior prediction models with economic variables: Farmer actions toward soil conservation. Journal of Social Psychology, 128(1), 19-28. http://dx.doi.org/10.1080/00224545.1988.9711680

Lynne, G. D., Shonkwiler, J. S., \& Rola, L. R. (1988). Attitudes and farmer conservation behavior. American Journal of Agricultural Economics, 70(1), 1219. http://dx.doi.org/10.2307/1241971

Matthews, T. W., Taylor, J. S., \& Powell, L. A. (2012). Mid-contract management of Conservation Reserve Program grasslands provides benefits for ringnecked pheasant nest and brood survival. Journal of Wildlife Management, 76(8), 1643-1652. http://dx.doi.org/10.1002/jwmg.409

Negus, L. P., Davis, C. A., \& Wessel, S. E. (2010). Avian response to mid-contract management of Conservation Reserve Program fields. American Midland Naturalist, 164(2), 296-310. http://dx.doi.org/10.1674/0003-0031-164.2.296

Nelson, E., Uwasu, M., \& Polasky, S. (2007). Voting on open space: What explains the appearance and support of municipal-level open space conservation referenda in the United States? Ecological Economics, 62(3-4), 580-593. http://dx.doi.org/10.1016/j.ecolecon.2006.07.027

Osborne, D. C., Sparling, D. W., \& Hopkins, R. L., II. (2012). Influence of Conservation Reserve Program mid-contract management and landscape composition on northern bobwhite in tall fescue monocultures. Journal of Wildlife Management, 76(3), 566-574. http://dx.doi.org/10.1002/jwmg.258 
Ostrom, E. (1999). Institutional rational choice: An assessment of the institutional analysis and development framework. In P. A. Sabatier (Ed.), Theories of the policy process (pp. 35-72). Boulder, Colorado: Westview Press.

Ostrom, E. (2005). Understanding institutional diversity. Princeton, New Jersey: Princeton University Press.

Ostrom, E. (2011). Background on the institutional analysis and development framework. Policy Studies Journal, 39(1), 7-27. http://dx.doi.org/10.1111/ j.1541-0072.2010.00394.x

Ostrom, E., Gardner, R., \& Walker, J. (1994). Rules, games, and common-pool resources. Ann Arbor, Michigan: University of Michigan Press.

Reichelderfer, K., \& Boggess, W. G. (1988). Government decision making and program performance: The case of the Conservation Reserve Program. American Journal of Agricultural Economics, 70(1), 1-11. http://dx.doi.org/10.2307/1241970

Reimer, A. P., Thompson, A. W., \& Prokopy, L. S. (2012). The multi-dimensional nature of environmental attitudes among farmers in Indiana: Implications for conservation adoption. Agriculture and Human Values, 29(1), 29-40. http://dx.doi.org/10.1007/s10460-011-9308-z

Ribaudo, M. O., Hoag, D. L., Smith, M. E., \& Heimlich, R. (2001). Environmental indices and the politics of the Conservation Reserve Program. Ecological Indicators, 1(1), 11-20. http://dx.doi.org/10.1016/ S1470-160X(01)00002-4

Roberts, M. J., \& Lubowski, R. N. (2007). Enduring impacts of land retirement policies: evidence from the Conservation Reserve Program. Land Economics, 83(4), 516-538.

Stubbs, M. (2013). Conservation Reserve Program (CRP): Status and issues (Congressional Research Service Report No. 7-5700). Retrieved from the National Agricultural Law Center website: http://nationalaglawcenter.org/crs/

Swanson, D. A., Scott, D. P., \& Risley, D. L. (1999). Wildlife benefits of the Conservation Reserve Program in Ohio. Journal of Soil and Water Conservation, 54(1), 390-394. http://www.jswconline.org/
U.S. Department of Agriculture [USDA]. (2006a). Fact sheet: Conservation Reserve Program continuous sign-up. Washington, D.C.: USDA, Farm Service Agency. Retrieved from http://www.fsa.usda.gov/Internet/ FSA File/crpcont06.pdf

USDA. (2006b). Farm bill forum comment summary \& background: Conservation Reserve Program and Conservation Reserve Enhancement Program (Farm Bill Forums Series). Retrieved from http://www.usda.gov

USDA. (2012). FS A bandbook: Agricultural Resource Conservation Program for state and county offices (2-CRP, Revision 5). Washington, D.C.: USDA, Farm Service Agency. Retrieved from https://www.fsa. usda.gov/Internet/FSA_File/2-crp_r05_a15.pdf

USDA. (2013a). Conservation Reserve Program fact sheet. Washington, D.C.: USDA, Farm Service Agency. Retrieved from https://www.fsa.usda.gov/ Internet/FSA File/crpfactsheet0213.pdf

USDA. (2013b). Conservation Reserve Program monthly summary: March 2013. Washington, D.C.: USDA, Farm Service Agency. Retrieved from http://www.fsa.usda.gov/Internet/FSA File/ mar2013stat.pdf

USDA. (2013c). Conservation Reserve Program Sign-Up 45 Environmental Benefits Index (EBI) fact sheet. Washington, D.C.: USDA, Farm Service Agency. Retrieved from http://www.fsa.usda.gov/ Internet/FSA File/crp signup45.pdf

U.S. General Accounting Office. (1989). Farm programs: Conservation Reserve Program could be less costly and more effective: Report to the Chairman, Committee on Agriculture, Nutrition, and Forestry, U.S. Senate (Report GAO/RCED-90-13). Gaithersburg, Maryland: Author. http://www.gpo.gov/fdsys/pkg/GAO REPORTS-RCED-90-13/pdf/GAOREPORTSRCED-90-13.pdf

Young, D., Bechtel, A. , \&, Coupal, R. (1994). Comparing performance of the 1985 and the 1990 Conservation Reserve Programs in the West. Journal of Soil and Water Conservation, 49(5), 484-487. http://www.jswconline.org/ 